\title{
Visual Acuity After Small-Incision Lenticule Extraction in the Early Postoperative Period: Low Myopia Versus Moderate to High Myopia
}

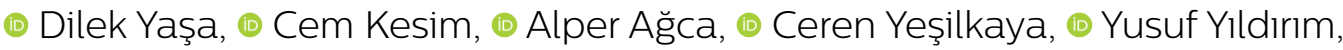 \\ (1) Burçin Kepez Yıldız, (ㄷ) Ahmet Demirok
}

Department of Ophthalmology, Prof. Dr. N. Reşat Belger Beyoğlu Eye Training and Research Hospital, İstanbul, Turkey

Submitted: 28.07 .2018 Accepted: 26.09 .2018

Correspondence: Dilek Yaşa Prof. Dr. N. Reşat Belger Beyoğlu Göz Eğitim ve Araştırma Hastanesi İstanbul, Turkey

E-mail: dilekyasa2@gmail.com

Keywords: Myopia;
refractive surgery; safety;
small-incision lenticule
extraction.

\begin{abstract}
Objective: This study aims to evaluate the effect of intended correction on early visual acuity after small-incision lenticule extraction (SMILE).

Methods: Medical records of patients who underwent SMILE for surgical correction of myopia were retrospectively reviewed. Patients with preoperative visual acuity $\geq 1.0$ and spherical equivalent (SE) of manifest refractive error within $\leq \pm 025 \mathrm{D}$ of emmetropia at I month were included in the study. The group with low myopia (Group I, SE $<3$ D) was compared to the group with moderate to high myopia (Group 2, SE >3 D). The main outcome measure was the corrected distance visual acuity (CDVA) at I-day, I-week, and I-month visits.
\end{abstract}

Results: The mean attempted SE was $-2.49 \pm 0.35 \mathrm{D}$ and $-4.65 \pm 1.29 \mathrm{D}$ in Groups I and 2, respectively. There was no statistically significant correlation between the intended correction and CDVA at I day, I week, or I month. At I day postoperation, 33\% and $8 \%$ of eyes in Groups I and 2 lost two or more lines of CDVA, respectively $(p=0.026)$. No patients lost two or more lines at I month.

Conclusion: The loss of two or more lines of CDVA after SMILE in the early postoperative period was more common among patients who had low myopia preoperatively. CDVA improved during the first month after SMILE.

\section{INTRODUCTION}

Small-incision lenticule extraction (SMILE) is a relatively new method for the surgical treatment of myopia. ${ }^{[l]}$ This method is similar to laser in situ keratomileusis (LASIK) surgery in that it is based on the removal of an intrastromal lenticule from the cornea to provide the necessary refractive correction. However, the femtosecond laser used in the SMILE operation can be focused into the stroma, in contrast to the excimer laser used in LASIK. Therefore, in the SMILE surgery, planned incisions are made in the stroma to form a lenticule, and the lenticule is removed from the stoma as a whole from a 2 to $3-\mathrm{mm}$ side cut. ${ }^{[2,3]}$ The absence of a flap in SMILE offers some advantages over LASIK..$^{[4,5]}$

One of the most notable points of the SMILE surgery is the relatively slow recovery in visual acuity, although the corneal surface is almost untouched (except for a superficial side cut that is used to remove the intrastromal lenticule) ${ }^{[3]}$ Even when the objective and subjective refraction measurements of the patient are within the intended ranges of correction, it is not uncommon for the corrected distance visual acuity (CDVA) to be less than the preoperative CDVA. Therefore, in clinical practice, each patient is informed that their visual acuity may not be satisfactory for some time postoperatively, and that there will be a slow recovery in the postoperative weeks.

According to our clinical observation, this condition is not as pronounced in every patient. Some patients may experience a loss of three to four lines even after postoperative emmetropia, while others do not experience a clinically significant loss in CDVA. No publications demonstrate which patients are more likely to experience a more pronounced decrease in CDVA. The reasons have not yet been established for the relatively slow recovery in CDVA and the factors that determine the rate of increase in CDVA. ${ }^{\left[{ }^{[6]}\right.}$

The aim of this study was to evaluate the effect of intended correction on early visual acuity after SMILE.

\section{MATERIAL AND METHODS}

This study was conducted in accordance with the Helsinki Declaration, and ethical approval was obtained from the 
institutional review board. The medical records of patients who underwent SMILE surgery were retrospectively reviewed. Patients with an intended target of emmetropia were included in the study if their visual acuities were obtained at I day, I week, and I month after the operation, and if their objective and subjective refractions were within $\leq \pm 0.25 \mathrm{D}$ of emmetropia at the I-month follow-up visit. Patients with preoperative CDVA $<1.0$ were not included in the study.

The eyes were divided based on preoperative refractive error into two groups: one with low myopia (Group I, $<3.00 \mathrm{D}$ ) and one with moderate to high myopia (Group 2, >3.00 D). UDVA and CDVA as well as the spherical equivalent (SE) of manifest refractive error were evaluated preoperatively and at I day, I week, and I month after the surgery. Before surgery, all patients had a detailed examination of the anterior and posterior segment, objective cycloplegic refraction examination, and subjective manifest refraction examination. Corneal topography was routinely carried out with all patients. The patients' visual acuities were recorded using the decimal system.

In all patients, preoperative refractive errors were stable for at least two years. Normal topography patterns were present in all eyes, and the thickness of the corneal was $>500 \mu \mathrm{m}$ at its thinnest point. The calculated residual stroma bed was $>300 \mu \mathrm{m}$ after the intended correction for all patients.

\section{Statistical analysis}

The statistical analysis was performed using SPSS Statistics 22.0 (IBM Corp., Armonk, USA). The descriptive statistics used were the mean, standard deviation, and minimum and maximum values. Categorical variables were assessed by the chi-squared test, while preoperative SE and postoperative visual acuity were assessed with the Pearson correlation analysis.

\section{RESULTS}

A total of 109 eyes from 78 patients were included in this study. There were 45 female patients (42\%) and 33 males (58\%). The mean age was $28 \pm 5$ years. The preoperative characteristics of the eyes in Group I and 2 are given in Table I. Preoperative SE and preoperative astigmatism were higher in Group 2. Table 2 shows the preoperative and postoperative CDVA in Groups I and 2. Because only patients who were within $\pm 0.25 \mathrm{D}$ of emmetropia were included in the study, CDVA was equal to UDVA in all examinations of all patients. In both groups, CDVA at day I postoperation was significantly lower than the preoperative CDVA at a statistically significant level. However, there was no statistically significant difference between preoperative and postoperative CDVA between the groups (Table 2).

When all patients were analyzed together, there was no significant correlation between the intended correction (D) and the amount of CDVA loss (logMAR) at any visit $\left(p=0.121,0.231\right.$ and 0.569 for $\left.\right|^{\text {st }}$ day, $\left.\right|^{\text {st }}$ week, $\left.\right|^{\text {st }}$ month visits, respectively). Table 3 demonstrates the correlation between loss in CVDA (logMAR) and SE of preoperative manifest refraction (D) in Groups I and 2. There was no significant correlation between the intended correction

Table I. Preoperative characteristics

\begin{tabular}{|c|c|c|c|}
\hline & Group I & Group 2 & $\mathbf{p}^{*}$ \\
\hline & Mean $\pm S D$ & Mean $\pm S D$ & \\
\hline Age (years) & $27 \pm 7$ & $28 \pm 5$ & 0.746 \\
\hline Mean keratometry (D) & $43.51 \pm 1.43$ & $43.61 \pm 1.25$ & 0.790 \\
\hline $\begin{array}{l}\text { Thinnest corneal } \\
\text { thickness }(\mu \mathrm{m})\end{array}$ & $546 \pm 41$ & $549 \pm 32$ & 0.770 \\
\hline SE (D) & $-2.49 \pm 0.35$ & $-4.65 \pm 1.29$ & $<0.001$ \\
\hline Astigmatism (D) & $0.23 \pm 0.33$ & $0.64 \pm 6 I$ & 0.026 \\
\hline
\end{tabular}

Table 2. Preoperative and postoperative corrected distance visual acuities

\begin{tabular}{|c|c|c|c|}
\hline & Group I & Group 2 & $\mathbf{p}^{*}$ \\
\hline & Mean士SD & Mean士SD & \\
\hline $\begin{array}{l}\text { Preoperative CDVA } \\
\text { (logMAR) }\end{array}$ & $0 \pm 0$ & $0 \pm 0$ & 0.727 \\
\hline $\begin{array}{l}\text { I-day CDVA } \\
\text { (logMAR) }\end{array}$ & $0.1 I \pm 0.1$ & $0.07 \pm 0.1$ & 0.171 \\
\hline $\begin{array}{l}\text { I-week CDVA } \\
\text { (logMAR) }\end{array}$ & $0.06 \pm 0.07$ & $0.03 \pm 0.08$ & 0.383 \\
\hline $\begin{array}{l}\text { I-month CDVA } \\
\text { (logMAR) }\end{array}$ & $0.02 \pm 0.04$ & $0.01 \pm 0.04$ & 0.384 \\
\hline$P^{* *}$ & $<0.001$ & $<0.001$ & \\
\hline
\end{tabular}

*Inter-group comparison, independent samples t-test, two-tailed $p$ value; **Within group comparison, paired samples t-test, two-tailed $p$ value; Group I: Preoperative- I day: $p=0.002$; I day- I week: $p=0.620$; I week $-I$ month: $p=0.016$; Preoperative-I month: $p=0,098$ (paired samples t-test, Bonferroni correction, two-tailed $p$ value); Group 2: Preoperative-I day: $p<0.001$; I day-I week: $p=p<0.00 I$; I week-I month: $p=0.00 I$; Preoperative-I month: $p=0,028$ (paired samples T-Test, Bonferroni correction, two-tailed $p$ value). CDVA: Corrected distance visual acuity; SD: Standard deviation.

Table 3. Correlation between loss in corrected distance visual acuity (logMAR) and spherical equivalent of preoperative manifest refraction (D)

\begin{tabular}{lcc}
\hline & Group I & Group 2 \\
\hline I-day visit & $r=0.129\left(p^{*}=0.690\right)$ & $r=0.101 \quad\left(p^{*}=0.325\right)$ \\
I-week visit & $r=-0.207\left(p^{*}=0.518\right)$ & $r=0.098\left(p^{*}=0.341\right)$ \\
I-month visit & $r=-0.426\left(p^{*}=0.167\right)$ & $r=0.033\left(p^{*}=0.747\right)$
\end{tabular}

r: Pearson correlation analysis, correlation coefficient; *Pearson correlation analysis, two-tailed $\mathrm{p}$ value. 
Table 4. Line loss at postoperative visits

\begin{tabular}{|c|c|c|c|}
\hline & $\begin{array}{c}\text { Group I } \\
\text { n (\%) }\end{array}$ & $\begin{array}{c}\text { Group } 2 \\
\text { n (\%) }\end{array}$ & $\mathbf{p}^{*}$ \\
\hline \multicolumn{4}{|c|}{ I day, CDVA loss } \\
\hline$<2$ lines & $8 / 12(67)$ & $89 / 97$ (91) & 0.026 \\
\hline$\geq 2$ lines & $4 / 12(33)$ & $8 / 97(8)$ & \\
\hline \multicolumn{4}{|c|}{ I week, CDVA loss } \\
\hline$<2$ lines & $11 / 12(92)$ & $94 / 97$ (97) & 0.377 \\
\hline$\geq 2$ lines & $\mathrm{I} / \mathrm{I} 2(8)$ & 3/97 (3) & \\
\hline \multicolumn{4}{|c|}{ I month, CDVA loss } \\
\hline$<2$ lines & $0 / 12(0)$ & $0 / 97(0)$ & 1.0 \\
\hline$\geq 2$ lines & $0 / 12(8)$ & $0 / 97(0)$ & \\
\hline
\end{tabular}

(D) and the amount of CDVA loss (logMAR) in Group I or Group 2. However, significantly more patients in Group I had lost two or more lines of CDVA at the I $^{\text {st }}$ day visit when compared to the patients in Group 2 (Table 4). There was no statistically significant difference between the groups at the $\mathrm{I}^{\text {st }}$ week and $\mathrm{I}^{\text {st }}$ month visits (Table 4).

\section{DISCUSSION}

This study aimed to evaluate the effect of intended correction on early visual acuity after SMILE. It has been reported that there is loss of CDVA in the early postoperative period, and that preoperative levels are reached later. $[2,3,6]$ In line with the literature, we found that patients with low myopia and patients with moderate to high myopia had significantly lower mean postoperative CDVA, but it recovered at I month. There was no significant difference between preoperative and postoperative examinations at I month in both groups in terms of mean CDVA, and none of the patients had lost two or more lines of CDVA at I month postoperatively. There was no significant correlation between the intended correction and the amount of CDVA loss at any visit. In addition, no significant difference was found between the visual acuities of both groups at I day, I week, and I month.

However, only a small proportion of patients experienced CDVA loss, and this may not significantly affect the overall average. Therefore, it can be misleading to conclude through only the averages in different postoperative visits. For this reason, groups were also compared in terms of the frequency of patients who experienced a loss of two or more lines of CDVA. Although there was no difference between the mean CDVAs on day I postoperation (Table 2, $p=0.325), 33 \%$ of the patients in Group I and $8 \%$ of the patients in Group 2 had lost two or more lines of CDVA (Table 4, $\mathrm{p}=0.026$ ). At week I, the proportion of those who lost two or more lines of CDVA was higher in Group $\mathrm{I}$, but the difference was not statistically significant. At the I $^{\text {st }}$ month visit, none of the patients had two or more lines of CDVA loss.
Other studies have reported that visual rehabilitation after the SMILE surgery is relatively slow. As far as we know, however, no other study has examined the association between the level of preoperative myopia and clinically significant loss of CDVA. ${ }^{[2,3,6]}$ The difference between groups in terms of CDVA loss may be related to the thickness of the removed lenticule. A recent study showed that increasing the minimum lenticule thickness in patients with low myopia increases the efficacy and safety of the SMILE surgery in these patients. ${ }^{[7]}$ Siedlecki et al. ${ }^{[7]}$ compared eyes with low myopia that were operated on with a programmed minimum lenticule thickness of $15-30 \mu \mathrm{m}$ (thicker lenticule group) to a group of eyes matched by SE and operated on with a minimum standard setting of 10 $\mu \mathrm{m}$. They reported that after SMILE, the thicker lenticule group showed better safety with fewer eyes losing one (3\% vs. $17 \%$ ) and two (0\% vs. $3 \%$ ) lines.

The major weakness of this study is its retrospective nature and the difficulty in performing visual acuity measurements in the early days postoperation. According to our experience, subjective and objective refraction measurements in the early postoperative period are difficult, and the loss of CDVA further complicates the issue. In addition, visual acuity measurements were performed by different residents at different visits in this study. To overcome these challenges, only patients who had an autorefractometer measurement and subjective manifest refraction within $\pm 0.25 \mathrm{D}$ of emmetropia at the $\mathrm{I}^{\text {st }}$ month visit were included in this study. In these patients, it was assumed that refractive errors were minimal at the examinations on day I and week I, and that the results of the incorrect examinations would only minimally affect the study results. One may argue that evaluating only patients with postoperative emmetropia is a shortcoming of this study. However, the amount of overcorrection or undercorrection, or in which eyes, is a separate study topic and was not the target of this study. The likelihood of a clinically significant undercorrection or overcorrection after the SMILE surgery (or permanent loss of two or more lines of CDVA) is very low, and it is similar to that of LASIK surgery. ${ }^{[8-1 I]}$

A second factor that may influence the correct assessment of CDVA loss is the preoperative CDVA of the patient. It is well established in the literature that a significant proportion of patients with high myopia experience two or more lines of improvement in CDVA after the surgical correction of high refractive error. ${ }^{[12,13]}$ Accordingly, if we had investigated patients who had CDVA $<1.0$, one could argue that the adverse effect of the SMILE surgery on CDVA could be compensated for by the improvement of CDVA after the correction of high refractive error, or at least in some patients. For example, for a patient with a preoperative and postoperative visual acuity of 0.6 (no loss of CDVA after SMILE), one could argue that the patient would have a CDVA of I.0 if the phakic IOL was used instead of SMILE. In our study, the evaluated eyes were in a wide range of low myopia to high myopia. Thus, only patients with CDVA $\geq 1.0$ were included so that the results were affected as little as possible by this phenomenon. 
In conclusion, patients with low and medium to high myopia had a decrease in CDVA after the SMILE surgery. We found that CDVA was lowest at the first postoperative day. It then improved gradually, and reached the same level as the preoperative state at the first month. In addition, although no patient lost two or more lines by I month postoperatively, the loss of two or more lines of CDVA in the early postoperative period was significantly more common in patients with low myopia when compared to patients with moderate to high myopia.

Ethics Committee Approval

This study was conducted in accordance with the Helsinki Declaration, and ethical approval was obtained from the institutional review board.

\section{Informed Consent}

Retrospective study.

Peer-review

Internally peer-reviewed.

Authorship Contributions

Concept: A.A., D.Y.; Design: DY., A.A., C.K.; Data collection \&/or processing: C.K., D.Y., C.Y., D.Y.; Analysis and/ or interpretation: D.Y., C.K., A.A., C.Y., Y.Y., B.K.Y., A.D.; Literature search: D.Y., B.K.Y.; Writing: D.Y., C.K., A.A., C.Y., Y.Y., B.K.Y., A.D.; Critical review: D.Y., C.K., A.A., C.Y., Y.Y., B.K.Y., A.D.

Conflict of Interest

None declared.

\section{REFERENCES}

1. Sekundo W, Kunert KS, Blum M. Small incision corneal refractive surgery using the small incision lenticule extraction (SMILE) procedure for the correction of myopia and myopic astigmatism: results of a 6 month prospective study. Br J Ophthalmol 2011;95:335-9.

2. Ağca A, Demirok A, Yıldırım Y, Demircan A, Yaşa D, Yeşilkaya C, et al. Refractive lenticule extraction (ReLEx) through a small incision (SMILE) for correction of myopia and myopic astigmatism: current perspectives. Clin Ophthalmol. 2016;10:1905-1912. eCollection 2016.

3. Shah R, Shah S, Sengupta S. Results of small incision lenticule extraction: All-in-one femtosecond laser refractive surgery. J Cataract Refract Surg 2011;37:127-37.

4. Demirok A, Ozgurhan EB, Agca A, Kara N, Bozkurt E, Cankaya KI, et al. Corneal sensation after corneal refractive surgery with small incision lenticule extraction. Optom Vis Sci 2013;90:1040-7.

5. Reinstein DZ, Archer TJ, Randleman JB. Mathematical model to compare the relative tensile strength of the cornea after PRK, LASIK, and small incision lenticule extraction. J Refract Surg 2013;29:45460 .

6. Agca A, Ozgurhan EB, Yildirim Y, Cankaya KI, Guleryuz NB, Alkin $Z$, et al. Corneal backscatter analysis by in vivo confocal microscopy: fellow eye comparison of small incision lenticule extraction and femtosecond laser-assisted LASIK. J Ophthalmol 2014;2014:265012.

7. Siedlecki J, Luft N, Keidel L, Mayer WJ, Kreutzer T, Priglinger SG, et al. Variation of Lenticule Thickness for SMILE in Low Myopia. J Refract Surg 2018;34:453-459.

8. Vestergaard A, Ivarsen AR, Asp S, Hjortdal JØ. Small-incision lenticule extraction for moderate to high myopia: Predictability, safety, and patient satisfaction. J Cataract Refract Surg 2012;38:2003-10.

9. Ivarsen A, Asp S, Hjortdal J. Safety and complications of more than 1500 small-incision lenticule extraction procedures. Ophthalmology 2014;121:822-8.

10. Reinstein DZ, Carp GI, Archer TJ, Gobbe M. Outcomes of small incision lenticule extraction (SMILE) in low myopia. J Refract Surg 2014;30:812-8.

11. Pedersen IB, Ivarsen A, Hjortdal J. Three-Year Results of Small Incision Lenticule Extraction for High Myopia: Refractive Outcomes and Aberrations. J Refract Surg 2015;31:719-24.

12. Stulting RD, John ME, Maloney RK, Assil KK, Arrowsmith PN, Thompson VM, et al. Three-year results of Artisan/Verisyse phakic intraocular lens implantation. Results of the United States Food And Drug Administration clinical trial. Ophthalmology 2008;115:464472.e1.

13. Agca A, Ozgürhan EB, Baz O, Bozkurt E, Ozkaya A, Yaşa D, et al. Laser in situ keratomileusis in adult patients with anisometropic amblyopia. Int J Ophthalmol 2013;6:362-9.

\section{Küçük Kesiden Lentikül Ekstraksiyonu Ameliyatı Sonrası Erken Dönemde Görme Keskinliği: Düşük Orta Miyopi ve Yüksek Miyopinin Karşılaştırılması}

Amaç: Hedeflenen refraktif düzeltmenin küçük insizyondan lentikül ekstraksiyonu (SMILE) sonrası erken dönemde görme keskinliğine etkisinin incelenmesi.

Gereç ve Yöntem: Miyopi nedeniyle SMILE cerrahisi uygulanan hastaların dosyaları geriye dönük olarak incelendi. Ameliyat öncesi görme keskinliği $\geq 1.0$ ve ameliyat sonrası birinci ayda sferik eşdeğeri (SE) $\leq \pm 0.25$ D olan hastalar çalışmaya alındı. Düşük miyopi grubu (Grup I, $\mathrm{SE} \leq 3.00 \mathrm{D}$ ) yüksek miyopi grubu ile (Grup I, SE >3.00 D) karşışşırıldı. Ameliayt sonrası birinci gün, birinci hafta ve birinci aydaki görme keskinlikleri değerlendirildi.

Bulgular: Düzeltilmesi hedeflenen SE, Grup I ve 2'de sırasıyla $-2.49 \pm 0.35 \mathrm{D}$ ve $-4.65 \pm$ I.29 D idi. Düzeltilmesi hedeflenen SE ile ameliyat sonrası birinci gün, birinci hafta ve birinci ay görme keskinlikleri (logMAR) arasında anlamlı bir korelasyon yoktu. Ameliyat sonrası birinci günde, en iyi düzeltilmiş görme keskinliğinde iki sıra ya da daha fazla kayıp olan hastaların oranı Grup I'de \%33 iken Grup 2'de \%8 idi ( $p=0.026$ ). Birinci ay muayenesinde hiçbir hastada iki sıra ya da daha üzerinde en iyi düzeltilmiş görme keskinliği kaybı bulunmuyordu.

Sonuç: Ameliyat sonrası erken dönemde en iyi düzeltilmiş görme keskinliği kaybı düşük miyopisi olan hastalarda daha sıktır. SMILE sonrası düzeltilmiş görme keskinliği ilk bir ay içerisinde düzelmektedir.

Anahtar Sözcükler: Güvenlik; miyop; refraktif cerrahi; küçük insizyondan lentikül ekstraksiyonu. 